\title{
OS HOMENS-FRONTEIRA: PROBLEMAS HISTÓRICOS E SOLUÇÕES FICCIONAIS EM ERICO VERISSIMO
}

\author{
Jocelito Zalla \\ jocelito.zalla@ufrgs.br
}

Um dos pontos mais problemáticos para a memória histórica no Rio Grande do Sul, pelo menos desde os esforços sistemáticos de narração empreendidos após a fundação do Instituto Histórico e Geográfico local, em 1920, é o da incorporação da tradição missioneira e do passado dos Sete Povos Orientais. Debates acalorados tomariam conta do espaço público rio-grandense até o bicentenário da Guerra Guaranítica, em 1955, com a lembrança da morte do corregedor de São Miguel, Sepé Tiaraju, em combate contra os portugueses. Para os opositores das missões, importavam os fatos de que os aldeamentos jesuítas respondiam administrativamente à coroa espanhola, o conflito tinha como mote a resistência à cessão da área para Portugal (em troca da Colônia de Sacramento), e a composição étnica indígena da população reduzida. Entre os argumentos dos defensores, se encontravam: a correspondência entre costumes missioneiros e dos antigos gaúchos, como o preparo da erva-mate e o apreço pela carne bovina; a existência no folclore local de narrativas sobre o período, a guerra, e o próprio Sepé, "canonizado" pelos grupos populares como "São Sepé"; além da inevitável miscigenação entre luso-brasileiros, indígenas e, inclusive, espanhóis, durante o longo período de fronteira móvel e porosa da região. 
Erico Verissimo conhecia bem o debate. Um amigo próximo, Moysés Vellinho, crítico literário e historiador, aglutinava a condenação da celebração missioneira no passado gaúcho, num projeto mais amplo de nobilitação do estado pela sua ligação étnica com Portugal e por sua suposta vocação militar. Para ele, o Rio Grande teria nascido da defesa da fronteira lusitana no sul da América, o que simbolicamente desautorizaria qualquer suspeita quanto à brasilidade do gaúcho rio-grandense. Outros intelectuais bastante próximos a Erico, como o ítalo-brasileiro Mansueto Bernardi, seu antecessor na editoria da Revista do Globo, defendiam a figura de Sepé por sua permanência na memória popular.

O objetivo deste artigo é avaliar as relações entre $O$ Continente, primeiro livro da trilogia $O$ tempo e o vento - dedicado à formação histórica do Rio Grande -, e a tradição letrada local. Não se trata de advogar a adesão de Verissimo ao regionalismo gaúcho, mas de verificar possíveis interlocuções. Sua oposição à produção regionalista então dominante, em literatura e historiografia, não configuraria seu projeto de romance histórico? Para responder a pergunta, não creio que baste, metodologicamente, reinserir o texto em seu contexto discursivo imediato. É importante identificar as soluções específicas de Verissimo a problemas compartilhados de memória, procedimento recorrente neste trabalho, mas também é necessário avaliar qual o rendimento ficcional da temática para o autor. Portanto, este artigo pretende verificar como Erico Verissimo se valeu do debate histórico para produzir literatura.

\section{FICÇÃO E CONTRAMEMÓRIA}

Para nosso autor, a difícil assimilação do patrimônio indígenamissioneiro na memória pública gaúcha se manifestou, primeiramente,

\footnotetext{
1 No primeiro volume de suas memórias, Solo de clarineta, publicado em 1973, Verissimo confessou admiração por trabalhos isolados de Simões Lopes Neto, Darcy Azambuja, Cyro Martins e Vargas Neto, junto à sua aversão pela gauchesca: "nunca morri de amores pelo regionalismo e, para ser sincero, tinha e ainda tenho para com esse gênero literário as minhas reservas, pois acho-o limitado e, em certos casos, com um certo odor de imobilismo anacrônico de museu" (VERISSIMO, 2005, p. 264). O desejo de contornar a perspectiva levou o autor a estudar meticulosamente o passado local, o que também fez com que questionasse a narrativa historiográfica escolar, cujos livros "apresentavam a história do nosso estado como uma sucessão aborrecível de nomes de heróis e batalhas entre tropas brasileiras e castelhanas" (VERISSIMO, 2005, p. 265).
} 
no recorte temporal de seu livro. Quando começar uma narrativa ficcional sobre a formação do Rio Grande? A construção em patamares do romance, com textos sucessivos relativamente autônomos, permitiu uma saída simbólica pouco comprometedora: o primeiro capítulo, "O sobrado I", cena de um episódio da Revolução Federalista de 1893-95, que se desdobra em mais seis partes intercaladas, tem como pano de fundo um Rio Grande do Sul brasileiro já formado e conhecido do leitor, ainda que não pacificado; o segundo capítulo, "A fonte", recua historicamente até 1745, à redução jesuítica de São Miguel. Se no eixo temporal nos encontramos com o passado missioneiro, no eixo narrativo somos guiados pelo Rio Grande que a ele se opôs. A solução formal inicial indica o tratamento temático ao longo do texto: mais do que se posicionar frente a problemas de memória, Erico contrabalança as diferentes perspectivas, oferecendoao leitora possibilidade de interpretação do passado e de adesão a uma ou outra narrativa. ${ }^{2}$

Maior em extensão e com argumentos e motivos específicos, "A fonte" pode ser lida como a primeira "novela" da complexa arquitetura de O tempo e o Vento. Nela, personagens fictícios, como o padre Alonzo e o jovem visionário Pedro, convivem com figuras históricas como Sepé Tiaraju e o administrador colonial e militar português Antônio Gomes Freire. Dois movimentos ficcionais se coadunam no desenvolvimento do entrecho: o acompanhamento da história política da região, respeitando dados e fatos conhecidos do conflito que contrapôs guaranis e padres jesuítas a espanhóis e portugueses; a construção do mito de Sepé na mentalidade popular, com referências implícitas à tradição literária local. O crescimento do personagem Pedro leva à intensificação do segundo procedimento: a suas habilidades artísticas e ao seu poder de premonição é creditada a origem da mitificação do corregedor de São Miguel. Em intertexto com a lenda "O lunar de Sepé", registrada literariamente em poesia narrativa por João Simões Lopes Neto, em 1913, Pedro chama a atenção dos concidadãos para uma cicatriz adquirida por Sepé em escaramuça contra as forças inimigas: "Olhem... Deus botou um lunar na testa de Sepé" (VERISSIMO, 2004, p. 83). ${ }^{3}$ Em outro momento da narrativa, o personagem compõe versos

2 A técnica narrativa do contraponto já fora utilizada nos romances urbanos dos anos 1930. Segundo Regina Zilberman, sua adoção pode ser creditada à influência de Aldous Huxley, traduzido por Erico para a Editora Globo (ZILBERMAN, 1980, p. 80).

3 "Lunar" em espanhol significa "pinta", "mancha", "sinal", não necessariamente em formato de lua. No poema de Simões, ele possui a forma de cruzeiro, passando ao céu, depois da morte do personagem, como o Cruzeiro do Sul. 
sobre o alferes real Tiaraju, "o homem que mais admirava na redução" (VERISSIMO, 2004, p. 72), como que antecipando a famosa poesia popular. O desfecho mágico da lenda simoniana é contemplado por uma das visões de Pedro, que anuncia a morte do corregedor: "A alma de Sepé subiu ao céu e virou estrela" (VERISSIMO, 2004, p. 87). ${ }^{4}$

Mas a história política é mais do que cenário, ela acomete os personagens, define seus rumos, participa da trama. E o próprio desenvolvimento ficcional obedece à fatalidade da conquista portuguesa. Aí se encontra grande espaço para a leitura lusitana do passado riograndense, ao gosto de intelectuais como Moysés Vellinho. A resistência guarani é digna de narração pela exemplaridade heroica, mas não se trata de uma defesa da causa. Esta se assentava ideologicamente numa categoria ainda contemporânea: o nativismo como sentimento de amor à terra natal, embrião da nação. Mas o narrador de Verissimo oferece outra motivação a Sepé e seus seguidores, a aversão aos portugueses:

Bradara ele corajosamente em face dos representantes de Portugal e Espanha que Deus e são Miguel haviam dado aquelas terras aos índios; e que se a comissão e os soldados espanhóis quisessem entrar nelas, seriam bem recebidos, mas que os portugueses, esses jamais poriam os pés naqueles campos (VERISSIMO, 2004, p. 78).

A tensa história de fronteira justificava o sentimento. As primeiras experiências missioneiras no território haviam sido devastadas por bandeirantes paulistas, que ainda se chocavam com as reduções do século XVIII na caça à mão de obra indígena ou na busca pelo gado selvagem que se disseminava na região. Verissimo aproveita este motivo para construção do personagem Pedro. Sua mãe, uma indígena não reduzida, chega em mau estado a São Miguel nas vésperas do parto, que lhe custa a vida. A pele da criança, mais clara do que a dos nativos, levanta a suspeita do padre Alonzo:

Aqueles malditos vicentistas! - pensou Alonzo. Não se contentavam com prear índios e levá-los como escravos para sua capitania: tomavam-lhe também as mulheres, serviam-se vilmente delas e depois abandonavam-nas no meio do caminho, muitas vezes quando elas já se achavam grávidas de muitos meses.

\footnotetext{
4 No poema simoniano: "E subindo para as nuvens,/Mandou aos povos - benção!/Que mandava o Deus-Senhor/Por meio do seu clarão.../E o - lunar - da sua testa/Tomou no céu posição...".
} 
Aquele não era o primeiro caso e certamente não seria o último (VERISSIMO, 2004, p. 61).

Um dos poucos motivos que escapa à lógica do contrapeso de versões e à ambiguidade interpretativa no texto de Verissimo é o da miscigenação. As missões jesuíticas podem ser vistas como "fonte" do futuro Rio Grande em razão, principalmente, da relativa continuidade étnica da população. Para os historiadores empenhados ideologicamente na "nacionalização" da região, o fato era incômodo. De um lado, conduzia à redefinição do panteão local, dedicado a militares portugueses. De outro, demonstrando o clima ainda pouco propenso à diversidade cultural na cena intelectual local, questionava a alegada branquitude do gaúcho rio-grandense. $\mathrm{O}$ personagem Pedro Missioneiro se torna para Erico, assim, um gancho narrativo e um elo simbólico entre o antes e o depois dos tratados de fronteira do fim do século XVIII. A segunda "novela", chamada "Ana Terra", quarta parte do primeiro volume de $O$ continente - se considerarmos como terceira a continuação da abertura do livro, "O sobrado II" -, narra a história de uma família paulista radicada no Continente de São Pedro, região ao sul de Laguna, último posto de colonização portuguesa contígua ao Brasil até a fundação do presídio de Rio Grande, na barra da Lagoa dos Patos, em 1737.

Nos esforços de ocupação do território, a coroa cedia sesmarias a paulistas e lagunistas e incentivava a migração de açorianos, o que dirigia a vocação econômica da região para o latifúndio pecuarista e possibilitava a fundação de vilas e pequenas cidades, cada vez mais em direção ao Rio da Prata. Nesse descampado vivia o casal Maneco e Henriqueta Terra, com seus três filhos, Horácio, Antônio e Ana, quando Pedro Missioneiro aparece moribundo num córrego próximo ao rancho. $\mathrm{O}$ personagem recebe cuidados e passa a trabalhar na estância, como que para saldar sua dívida moral com a família. Sua história sintetiza a sina de muitos dos indígenas reduzidos legados ao lado português da fronteira, finda a Guerra Guaranítica: participara de conflitos pela demarcação de terras, aprendera a se comunicar em um dialeto misto de espanhol e português e trabalhara temporariamente na criação de gado. Sua permanência na estância dos Terra é simbolicamente autorizada pelos serviços militares prestados a Rafael Pinto Bandeira, personagem histórico que fora líder

5 O texto passou a ser publicado de forma independente a partir de 1971. 
das campanhas portuguesas na região e governador da Capitania de São Pedro do Rio Grande do Sul (1784). Mas Ana e Pedro acabam se envolvendo e, ao descobrir a união amorosa, e a desonra sexual, Maneco e os filhos assassinam o índio. Da relação, porém, nasce uma criança, mais uma esperança de vitória da sociedade nascente contra a terra inóspita. Do pai morto, o menino herda o nome Pedro e um antigo punhal espanhol trazido para os Sete Povos pelo padre Alonzo.

Na temática maior da formação do Rio Grande, apenas outro motivo parece contar com um posicionamento via narração/argumento, o da escravidão no estado. Na memória histórica oficial, sempre se minimizou o concurso à mão de obra escrava no latifúndio pecuarista. Tanto em número como em grau de violência. Na década de 1920, historiadores como Jorge Salis Goulart defendiam que o trabalho livre preponderava na criação de gado; havendo escravos negros, sua condição seria análoga à dos peões brancos, sem o sofrimento do castigo físico e a segregação da senzala, além da ausência de conflito na relação peão/patrão. A ambição de Maneco Terra contraria a imagem. Ao olhar para sua lavoura de milho, mandioca e feijão, o personagem sonha com um grande trigal. $\mathrm{O}$ negócio exigiria a contratação de peões e a compra de escravos (VERISSIMO, 2004, p. 128). No entanto, o crescimento da plantação só levaria à segunda opção. Quando a estância é assaltada por bandidos castelhanos e todos os homens da casa assassinados, a hierarquia racial se mantém na encomenda dos corpos. Aos Terra cabia o respeito cristão e a singularidade na cruz improvisada, aos negros a vala comum. Dias depois, Ana lembra que não conferira a respiração de um dos escravos. Sente-se culpada pela possibilidade de tê-lo enterrado vivo, mas resigna-se com certa rapidez. No destino final de Ana e de seu filho Pedro, após a destruição da estância, o vilarejo de Santa Fé, a situação era semelhante. A família Amaral, dona da maior parte das terras na área, contava com escravos domésticos e de produção: "Em princípios de 1804, Chico Amaral fundou uma charqueada e comprou mais um lote de escravos" (VERISSIMO, 2004, p. 185). Com o crescimento da vila, a diversificação das atividades e o enriquecimento de pequena parcela da população, os escravos domésticos passam a figurar com frequência na narrativa. Na novela seguinte, intitulada "A Teiniaguá" (outra referência a uma lenda registrada por Simões Lopes Neto), o enforcamento do escravo Severino, amigo de infância do protagonista masculino, Bolívar Terra Cambará, persegue a consciência desse último. Tendo sido acusado, talvez injustamente, por assassinato, apenas um 
depoimento confuso de Bolívar garantia a condenação. $O$ narrador não elucida a misteriosa morte de dois viajantes que pernoitavam na casa do senhor de Severino, mas aproveita o desencontro de versões para desenhar a psicologia de Bolívar, cambaleante entre a culpa por crimes cometidos contra castelhanos na última guerra de fronteira e a perspectiva de futuro promissor, garantido por um casamento arranjado. De certa forma, sua compaixão em relação ao negro contrasta com a fatalidade com que a execução pública é aceita e a naturalidade dessa experiência de morte na ótica dos demais homens e mulheres brancos. O outro extremo da escala de posicionamento frente ao destino de Severino é dado pela atitude de sua noiva Luzia, a teiniaguá do episódio, mulher bonita e má que representava a riqueza financeira e a decadência moral, como a princesa moura da lenda simoniana. O racismo declarado da jovem se choca contra a consciência pré-liberal de Bolívar, denunciando o absurdo do sistema racial vigente no passado gaúcho. "Negro não é gente", diz Luzia, que também nega a razão científica, representada no texto pelo médico alemão radicado em Santa Fé, doutor Carl Winter: "Não sei se o que eu disse é científico ou não. Mas é o que sinto. Para mim o negro está mais próximo do macaco do que dos seres humanos" (VERISSIMO, 2004b, p. 73).

É importante apontar para a relação dos dois motivos, miscigenação e escravismo, que explica internamente seu tratamento. Se outros pontos problemáticos da memória histórica local poderiam ser encaminhados à interpretação do leitor, a formação humanista de Erico e suas simpatias políticas pela esquerda democrática não permitiam escusas quanto à discriminação racial. ${ }^{6}$ Décadas depois, a historiografia crítica dos anos 1980 denominaria acertadamente os dois temas da memória histórica tradicional de "mito da miscigenação que não houve" e "mito da democracia sulina". 7 Se eles aparecem em poucos momentos da narrativa, é no ângulo de algum personagem comprometido, em certa medida, com o status quo. Assim, o padre Lara, na Santa fé dos anos 1820, busca em pensamento uma explicação para o mundo que via se formar, nivelando a crítica da criminalidade à falta de hierarquia social rígida: "Aquela vida agreste e livre convidava à violência, à arbitrariedade e à insubmissão. As

6 Quanto à ideologia humanista e seu amadurecimento na ficção de Erico, Chaves indica O tempo e o Vento como obra de superação de suas contradições internas (CHAVES, 2001, p. 68).

7 Ver GONZAGA, 1980. 
charqueadas eram foco de banditismo. O trabalho das estâncias como que nivelava o patrão ao peão e ao escravo" (VERISSIMO, 2004, p. 265). Uma curiosidade quanto às consequências da "mistura de raças" na província também incomoda o pároco de Santa Fé. Mesmo num ponto de vista tradicional, portanto, a miscigenação era irrefutável. O devaneio do personagem traz à tona, ainda, a relação entre brancos e negros:

\begin{abstract}
Sabia que era uma espécie de tradição entre os Amarais fazer filhos nas escravas, produzir mulatos e mulatas, que por sua vez depois se cruzavam com brancos, índios ou pretos. Os brancos gostavam muito das índias. $\mathrm{O}$ padre ouvira dizer que as mulheres índias se entregavam aos índios por obrigação, aos brancos por interesse e aos negros por prazer. Agora - refletia ele - aquele moço de sangue açoriano ia casar-se com a filha de Joca Rodrigues, que era um paulista neto de portugueses do Minho. Fazia já mais de quatro anos que tinham chegado à Feitoria do Linho-Cânhamo, às margens do rio dos Sinos, centenas e centenas de colonos alemães. No futuro os filhos desses imigrantes haveriam de fatalmente casar-se com as gentes da terra e o sangue alemão se misturaria com o português, o índio e o negro. Para produzir... o quê? (VERISSIMO, 2004, pp. 266-267).
\end{abstract}

\title{
O RIO DA PRATA COMO ALTERIDADE
}

Alguns comentaristas já apontaram para a relevância simbólica do filho de Ana Terra e Pedro Missioneiro. Mas, nesse caso, o reconhecimento da miscigenação não pode ser confundido com uma adesão irrestrita à tradição dos Sete Povos. Se ela pode ter existido, o escritor preferiu seguir, como dito, a história política da conquista lusitana, mantendo um olhar complexo para as relações sociais daí advindas. Um dado extratextual ajuda a pensar sobre a questão: um de seus editores, José Otávio Bertaso, conta que o título inicial do primeiro livro da trilogia seria "O punhal de Prata". Esse objeto, queacompanha as gerações de Cambará Terra, até o portentoso sobrado da família republicana, no começo do século XX, não perde sua função narrativa, costurando vínculos entre personagens e gerações. Mas a opção final pelo também significativo título de "continente", uma das primeiras denominações da área para a administração portuguesa, diminui seu peso na arquitetura simbólica.

8 No texto de apresentação à autobiografia de Erico, Solo de Clarineta. Ver BERTASO, 2004 . 
No plano das relações intertextuais, pelo menos duas citações de narrativas populares são importantes: o poema anônimo Nau Catarineta, recolhido em Portugal por Almeida Garret, em 1843; e versos da Chamarrita, canção açoriana disseminada no folclore gaúcho, recolhida, entre outros, por Simões Lopes Neto, em 1910. A escolha dos textos é simbolicamente adequada à perspectiva de narração dominante. À exceção do episódio chamado "O sobrado", dividido em sete partes, cada capítulo/ novela é seguido de um trecho narrativo independente, destacado em itálico, em que movimentos paralelos ao argumento principal ganham espaço: sintetizam acontecimentos ocorridos entre as partes maiores, introduzem algum personagem ou família que terá destaque na parte seguinte, apresentam fatos políticos relevantes na história do Rio Grande. No trecho que acompanha "A fonte", conhecemos Zé Borges e Chico Rodrigues. O primeiro chega dos Açores embalado pelos versos da Nau: "Sobe, sobe meu gajeiro/Àquele mastro real./Vê se vês terras d'Espanha,/ Areias de Portugal”. Passados os anos, constitui família e lavoura de trigo. A terra que produz o sustento lhe mata dois filhos, mas casa duas filhas. A terceira, Maria Rita, é apresentada com os versos da Chamarrita, por ela dançada: "Encontrei a Chamarrita/No mato fazendo lenha,/C'o seu colete redondo/Sua saia de estamenha”. Já a origem de Chico Rodrigues é incerta, mas subtende-se que nascera no Continente, sendo provável descendente de paulistas ou lagunistas, que há mais tempo chegaram ao território. Adaptara-se às condições da fronteira, com suas guerras contínuas e seu banditismo generalizado, criando fama pela valentia e crueldade:

\begin{abstract}
Apossava-se de terras sem requerer carta de sesmaria, assaltava tropas, roubava gado, andava sempre com uma índia na garupa enquanto alguém num povoado ou estância bradava: “Aí vem o Chico Rodrigues!", a gritaria começava, as mulheres fugiam para o mato, os homens pegavam nas espingardas, era um deus nos acuda (VERISSIMO, 2004, p. 91, grifo do autor).
\end{abstract}

Nesse ponto, outra união de personagens é simbolicamente construída, apesar de seu pequeno desdobramento narrativo. Através de versos do cancioneiro português, sabemos que Maria Rita está apaixonada: "Aqui tens meu coração,/Se o quiseres matar bem podes:/Olha que está dentro dele,/Se o matas, também morres". Chico Rodrigues com ela se casa, deixando as atividades ilícitas da fronteira: "Resolvi mudar de vida, requerer sesmaria, fazer casa, parar quieto, ser um senhor estancieiro, ter mulher, gado, cavalos e filhos, todos com a minha marca" (VERISSIMO, 2004, p. 93). Olhando para uma árvore forte à beira da estrada, decide 
também mudar de nome. Vira Chico Cambará; e descobrimos no casal uma das origens do clã Terra Cambará que se forma na novela seguinte, "Um certo capitão Rodrigo". 9

A história da família se confunde, assim, com a consolidação do território luso-brasileiro no sul da América. No mesmo segmento, o narrador afirma que homens como Chico Cambará havia centenas. E as patas de seus cavalos ampliavam as linhas divisórias do Continente de Rio Grande de São Pedro:

Queremos as ricas campinas do oeste e as grandes planícies do sul!

Só caranguejo é que fica na beira da praia papando areia.

Pelos campos de Rio Pardo iam entrando na direção do poente, demandando as Missões. Ou desciam costeando as grandes lagoas, rumo ao Prata.

E em todas as direções penetravam na terra dos minuanos, tapes, charruas, guenoas, arachanes, caaguás, guaranis e guaranás.

A fronteira marchava com eles. Eles eram a fronteira (VERISSIMO, 2004, p. 92, grifo do autor).

À medida que os continentinos se aproximam do Rio da Prata, este fica cada vez mais distante. As trocas existem, transparecendo inclusive na linguagem dos personagens, ${ }^{10}$ mas as relações são marcadas pelo conflito e mútua aversão. As décadas finais do século XVIII configuram a vida local pelos próximos decênios: "A princípio tinham sofrido os castelhanos, que dominaram o Continente por uns bons treze anos e que de tempos em tempos surgiam em bandos, levando por diante o gado alheio, saqueando casas, matando os continentinos, desrespeitando as mulheres" (VERISSIMO, 2004, p. 103).

O trabalho de perspectivação da narrativa permite o trânsito entre movimentos migratórios, correntes históricas e possibilidades identitárias no passado imaginado, configurando, como vimos, desenvolvimentos ficcionais paralelos no romance. A interpretação lusitanista da formação do Rio Grande transparece no ângulo de personagens comprometidos, mais por interesses pessoais do que por filiações pátrias, com a ocupação

\footnotetext{
9 Um certo capitão Rodrigo passou a ser editado em livro independente a partir de 1970. 1o Seguindo as recomendações modernistas, Erico é discreto no emprego de vocabulário regional na caracterização da fala, evitando a caricatura corrente na prosa regionalista da virada do século, principalmente. Exemplos de aproveitamento do linguajar local, de influência hispânica, na representação literária são os empregos da forma "mui" para o advérbio "muito", do diminutivo "ito" ao invés de "inho", e da forma "le" para o pronome de objeto indireto "lhe".
} 
luso-brasileira da fronteira sul. Dessa forma, possíveis dissidências internas podem emergir no texto. O velho Maneco Terra, por exemplo, critica a legenda de Rafael Pinto Bandeira, o que pode conotar conflitos entre lavradores e criadores de gado: "Patriota? Ele está mas é defendendo as estâncias que tem. O que quer é retomar as suas terras que os castelhanos invadiram. Pátria é a casa da gente" (VERISSIMO, 2004, p. 106). Contudo, a afirmação da base comum de interesses, a manutenção do domínio português sobre o Continente, exige, no plano simbólico, a invenção do inimigo, atribuindo ora ao nativo, ora ao castelhano, a responsabilidade única pelos crimes de fronteira. É assim que Dona Henriqueta entende a violência na região:

Ouvi contar histórias horríveis de mulheres que tinham sido roubadas e levadas como escravas pelos índios coroados, que acabavam obrigando-as a casarem com algum membro da tribo. Contavam-se também casos tenebrosos de moças que eram violentadas por bandoleiros. Seria mil vezes preferível viver como pobre em qualquer canto de São Paulo a ter uma estância, gado e lavoura ali naquele fundão do Rio Grande de São Pedro (VERISSIMO, 2004, p. 108).

Nesse universo em formação, as acomodações das forças internas exigem a permanente renovação de suas alianças frente a ameaças externas, daí o estado de guerra, também constante, experimentado na província. A figura do castelhano paulatinamente assume a exclusividade na alteridade rio-grandense, pelo menos enquanto a frente de combate se dirigir à delimitação das fronteiras, conferindo unidade à diversidade social e étnica local: "Mas que ia ser de nós sem os soldados? - perguntou Antonio. - Essa castelhanada vive nos atacando" (VERISSIMO, 2004, p. 125). A percepção das personagens, assim, contrapõe-se à realidade factual objetiva, tomando o avanço lusitano como direito consagrado e esquecendo-se das ofensivas militares e assaltos realizados na Banda Oriental." A função do inimigo na confecção de laços internos é exemplificada na altercação entre o capitão Rodrigo Cambará e o coronel Ricardo Amaral. Pese a pertença à mesma elite militar, as desavenças entre eles se instauram com a chegada do primeiro a Santa Fé. Reconhecendo a autoridade política do potentado local, Rodrigo informa a decisão de morar na vila, como quem pede guarida a alguém da mesma casta. A reação negativa de Amaral é sentida como a pior ofensa: "O coronel está

11 Denominação histórica para o atual território do Uruguai. 
me tratando como se eu fosse um castelhano, um estrangeiro, um inimigo" (VERISSIMO, 2004, p. 251).

\title{
A GUERRA COMO IDENTIDADE
}

Uma vez estabelecidos os limites políticos com o Prata, as disputas intraoligárquicas ganham espaço. Assim, o movimento macro na estrutura do romance se confunde com a história militar local, em detrimento de outros recortes possíveis. O sentido da narrativa aponta para a fatalidade da guerra, presente na conquista e na consolidação interna do território, e seus desdobramentos na personalidade gaúcha. Um personagem histórico, Pinto Bandeira, ganha voz na primeira novela para explicar a condição do sul: "A sina da gente é andar no lombo dum cavalo, peleando, comendo às pressas aqui e ali, dormindo mal ao relento pra no outro dia continuar peleando" (VERISSIMO, 2004, p. 105). O cerco do sobrado, que emoldura as partes relativamente autônomas do livro, é vivido pela velha Bibiana Terra como costume:

\begin{abstract}
Mas guerra para ela não é novidade. Tudo isso já aconteceu antes, muitas, muitas vezes. Viu guerras e revoluções sem conta, e sempre ficou esperando. Primeiro, quando menina, esperou o pai; depois o marido. Criou o filho, e um dia o filho também foi para a guerra. Viu o neto crescer, e agora o Licurgo está também na guerra. Houve tempo em que ela nem mais tirava o luto do corpo. Era morte de parente em cima de morte de parente, guerra sobre guerra, revolução sobre revolução. Como o tempo custa a passar quando a gente espera! Principalmente quando venta. Parece que o vento maneia o tempo (VERISSIMO, 2004, p. 40).
\end{abstract}

O emprego do discurso indireto livre, complemento da pluralidade de vozes em contraponto, mais do que à psicologia de Bibiana, dá aqui acesso à experiência feminina de guerra, que ultrapassa biografias, grupos sociais e gerações. Se a rotina bélica oferece, assim, uma chave de explicação histórica ao presente republicano, no ângulo da personagem, e um leitmotiv para ficção e realidade, no obra de Verissimo, o patriarcado rural condiciona a primeira cisão no ethos local. Ao homem cabe a introjeção da belicosidade, que se efetiva em bravura ou crueldade, heroísmo ou bestialidade gratuita. À mulher cabe a resignação, numa aceitação do destino que não implica sujeição à desordem, o que lhe dota de uma força moral necessária para a sustentação da família e da sociedade na ausência do pai, do marido ou do filho. O motivo da espera feminina 
perpassa, assim, as trajetórias de Ana, Bibiana, Maria Valéria, entre outras, tornando-se uma tópica comum na literatura de Verissimo. Se no plano da ficção o tema rende personagens femininas marcantes, no plano da interpretação histórica há uma valorização até então inédita do papel da mulher na construção do Rio Grande. As exigências sociais da guerra se condensam, por exemplo, no episódio em que Ana Terra tenta livrar seu filho Pedro do recrutamento forçado, nas hostes do líder de Santa Fé, o estancieiro Ricardo Amaral, durante a campanha da Cisplatina. Este chega a questionar a hombridade de Pedro, quando Ana apela, sem sucesso, à pouca idade do filho. É também em termos de gênero que o coronel nega a demanda: “- Vosmecê volte pra casa - disse Ricardo. - Volte e não conte a ninguém que veio me pedir pra dispensar seu filho. Não conte, que é uma vergonha" (VERISSIMO, 2004, p. 178). O constrangimento é, na verdade, duplo: do homem que foge da luta; da mulher que lhe sonega o apoio para a guerra.

Se o estado de belicosidade é comum, sua experiência é, portanto, específica. No mesmo episódio, a clivagem social também se revela na resistência interna de Ana Terra ao destino de Pedro:

\footnotetext{
Teve ganas de dizer que não tinha criado o filho para morrer na guerra nem para ficar aleijado brigando com os castelhanos. Guerra era bom para homens como o coronel Amaral e outros figurões que ganhavam como recompensa de seus serviços medalhas e terras, ao passo que os pobres soldados às vezes nem o soldo recebiam. Quis gritar todas essas coisas mas não gritou. A presença do homem - aquelas botas pretas, grandes e horríveis! - a acovardava (VERISSIMO, 2004, p. 179).
}

A vocação militar do Rio Grande, como sabemos, era um lugarcomum na memória histórica local. Como vimos, a historiografia de viés oficial tendia a celebrar em seu panteão de heróis os estancieirossoldados que lideraram a conquista e a manutenção do território ou que disputaram posição de liderança no cenário nacional. Nele havia lugar para Gomes Freire e Pinto Bandeira, para o Bento Gonçalves que comandaria a Revolução Farroupilha e ao Manuel Osório sempre fiel ao império. Mas as legendas populares eram negócio do folclore e da literatura de registro. Erico Verissimo aproveita, assim, a tradição literária de narrativa marginal para cantar as glórias e amarguras esquecidas pela história, como o mito de Sepé ou a vida miúda do campesino rio-grandense. Mas não se restringe a essa possibilidade dada pela produção letrada precedente, relatando, sem euforia, a dinâmica interna da elite militar e latifundiária, revelando 
suas fissuras e seu lento processo de decadência, concomitante à ascensão da burguesia urbana e de origem alemã ou italiana no estado. Além da denúncia dos crimes de fronteira, da dominação racial, do sistema de gênero, também há considerável espaço em seu romance para a crítica da guerra, na contramão da apologia historiográfica. Cabe ao Pedro Terra de idade avançada lembrar-se dos efeitos perversos dos incontáveis conflitos que devastaram o Rio Grande na primeira metade do século XIX:

Pedro sentia ainda no corpo o vestígio das guerras em que tomara parte. Depois de 1811 ficara sofrendo de reumatismo e duma dor nos rins, tudo isso como consequência de dormir em banhados, de tomar chuva e de carregar muito peso. Vezes sem conta tivera de empurrar roda de carroça e puxar canhão, como se fosse um cavalo. Além disso, passara fome ou estragara o estômago comendo carne podre e charque bichado. Aquela era a sina dos habitantes da Província de São Pedro. Pagavam muito caro por viverem tão perto da fronteira castelhana (VERISSIMO, 2004, p. 233).

Ao propor uma visão de dentro do fenômeno perseguido, Erico constrói um dos personagens mais marcantes de sua obra, o capitão Rodrigo Cambará, tipificação do código de honra masculina instaurado pelo estado de guerra: "Vosmecê já viu peixe fora d'água? Pois aqui está um. Na paz me sinto meio sem jeito” (VERISSIMO, 2004, p. 221). Tomando parte nos conflitos de fronteira desde a mais tenra idade, sua personalidade se faz forte pela disposição à luta e pelo temperamento sanguíneo, com aversão à rotina e à tranquilidade. É o perfeito produto do meio, como se percebe em sua avaliação sobre a condição da terra natal, exposta ao futuro cunhado, Juvenal Terra:

- Escuta o que vou le dizer, amigo. Nesta província a gente só pode ter como certo uma coisa: mais cedo ou mais tarde rebenta uma guerra ou uma revolução. - Atirou ambos os braços para o lado, num gesto de despreocupação. - Que é que adianta plantar, criar, trabalhar como burro de carga? O direito mesmo era a nossa gente nunca tirar o fardamento do corpo nem a espada da cinta. Trabalhar fardado, deitar fardado, comer fardado, dormir com as chinocas fardado... O castelhano está aí mesmo. Hoje é Montevidéu. Amanhã, Buenos Aires. E nós aqui no Continente sempre acabamos entrando na dança (VERISSIMO, 2004, p. 218).

Seu grande drama pessoal é a incapacidade de domesticar o próprio gênio, frente ao desejo de constituir família com a amada Bibiana Terra. Durante alguns anos, Rodrigo vive em Santa Fé como dono de um bolicho (armazém de produtos variados), em sociedade com o cunhado, mas a 
insatisfação com a vida à paisana leva a constantes conflitos com clientes, a bebedeiras e jogatinas sem fim e à acumulação de casos extraconjugais, até que estoura a Revolução Farroupilha. E o peixe retorna à água ao lado dos rebeldes.

Esse mesmo ethos masculino personificado em Rodrigo Cambará será alvo de desdém de um estrangeiro atento, na novela seguinte, "A teiniaguá”. Dessa vez, a visão "desde fora” do médico alemão Carl Winter permite ao narrador empreender uma aguda crítica ao par complementar machismo/violência:

\begin{abstract}
O código de honra daqueles homens possuía um nítido sabor espanhol. Falavam muito em honra. No fim das contas o que realmente importava para eles era "ser macho". Outra preocupação dominante era a de "não ser corno". Não levar desaforo pra casa, saber montar bem e ter tomado parte pelo menos numa guerra eram as glórias supremas daquela gente meio bárbara que ainda bebia água em guampas de boi. E a importância que o cavalo tinha na Província! Para os continentinos o cavalo era um instrumento de trabalho e ao mesmo tempo uma arma de guerra, um companheiro, um meio de transporte; para alguns gaúchos solitários as éguas serviam eventualmente de esposa (VERISSIMO, 2004b, pp. 55-56).
\end{abstract}

A moral de cavalaria, defendida pelos nativos, transforma-se, assim, num código ultrapassado, que terá seu ocaso local na tardia ascensão das classes médias urbanas e da burguesia industrial. Mas revela uma possibilidade de existência real, ao longo do século XIX, que encontra em Rodrigo Cambará o tipo ideal, ainda que nos demais continentinos, como Pedro e Juvenal Terra, represente uma questão de grau. Talvez a condenação da violência se manifeste no destino do capitão, se nele pudermos ver algo de simbólico: àqueles que abraçam em absoluto o estado de guerra, é justa a morte em batalha.

Por último, é necessário examinar a relação do romance com um dos maiores temas da história rio-grandense, objeto de debates acalorados e investimentos ideológicos recorrentes: a chamada Revolução Farroupilha ou Guerra dos Farrapos (1835-1845). ${ }^{22}$ Desde, pelo menos, o surgimento do Partido Republicado Rio-Grandense, no final do século XIX, a produção histórica local começava a resgatar o episódio do ostracismo político nacional. A malsucedida contenda separatista, que envolveu parcela 
da elite pecuarista da província contra a política tributária do governo imperial, passa a paulatinamente ser vista como uma antecipação do destino republicano do Brasil. Nos anos 1920, o empenho letrado em promover o projeto getulista de tomada do poder leva a uma inédita confusão entre propaganda, literatura e historiografia. É o tempo do gaúcho heroico, como vimos acima, cujo passado idealizado justifica as pretensões das novas elites locais. ${ }^{13}$ A contrapartida necessária daafirmação das peculiaridades gaúchas é a assunção da brasilidade rio-grandense. Assim como o separatismo, os vínculos da liderança farroupilha com os caudilhos platinos e sua atuação no Uruguai precisam ser minimizados.

O tratamento dado por Erico Verissimo ao tema não escapa à lógica geral do contraponto de versões. Todavia, se todas as opiniões quanto ao conflito afloram na ficção, a solução formal é distinta. Ao invés de desenvolver linhas paralelas de ação e construir grandes conflitos entre personagens cujos interesses se chocam, neste caso a opção narrativa é projetar no passado as discussões do presente. O evento é tomado como pano de fundo para a vida de Santa Fé. Alguns de seus personagens tomam parte no episódio, como o capitão Rodrigo, no lado farrapo, e o coronel Amaral, no lado legalista; mas, no geral, a situação da vila pouco muda, pelo menos até o assalto da residência do potentado local, comandado pelo capitão, que se encerra com a morte de ambos. Assim, os santa-fezinos assistem e comentam o desenrolar das disputas, consumindo notícias e boatos com avidez. A possível ligação entre Bento Gonçalves e Juan Antonio Lavalleja, um dos libertadores da Província Cisplatina, tematizada na literatura de ficção desde $O$ gaúcho, de José de Alencar, também comparece no romance. No bolichode Rodrigo Cambará sediscute a lealdade do líder farrapo, que estaria prestes a entregar o Rio Grande aos castelhanos: "É uma mentira. Conheço o coronel Bento Gonçalves!, afirma Rodrigo, pessoalmente ofendido. "E quem falar do coronel Bento

13 Sobre o mito do gaúcho heroico na historiografia tradicional, ver Gutfreind (1992). Sobre o papel da literatura de imaginação na propaganda da elite local na década de 1920, ver Leite (1978). Mais recente é o balanço da literatura regionalista gaúcha do período realizado por Luciana Murari (2010), que confirma nessa produção tarefas ideológicas muito semelhantes àquelas desempenhadas paralelamente pela primeira geração de historiadores "oficiais", membros do recém-fundado IHGRS, como Othelo Rosa e Rubens de Barcellos. Em termos idênticos aos verificados por Gufreind na historiografia, os literatos passaram insistentemente a construir heróis, inventariar tradições e peculiaridades locais, mas inserindo, com protagonismo político, a região no seio da nação. 
briga comigo!" (VERISSIMO, 2004, p. 321). Diferentemente de Alencar e outros antecessores, não há ação narrada entre os personagens históricos que referende uma ou outra opinião. Após o cerco de Santa Fé, e a adesão da Câmara Municipal à revolução, a novela termina e o desdobramento dessa guerra na vida local é desconhecido. A próxima parte do livro, "A teiniaguá", inicia-se com um pulo temporal de cerca de vinte anos, após o apaziguamento interno (temporário) frente, mais uma vez, à ameaça de expansão platina de 1850, representada pelo governo argentino de Rosas.

Apesar do tratamento formal, o narrador não se furta de uma interpretação geral do cenário político rio-grandense, mas como um historiador que escrutina causas e consequências, ele desenha antecedentes econômicos e culturais. Em outro distanciamento em relação à historiografia local, a razão profunda da guerra, mais do que oposição ao centralismo imperial ou, na versão mais ufanista, luta pela liberdade e pela república, poderia ser buscada na divisão geográfica estabelecida pelo modelo de colonização: na fronteira, latifúndio pecuarista, com agenciamento de populações tradicionais e militarização da sociedade; no litoral, lavoura, comércio e incentivo à imigração. As posições dos rio-grandenses frente à independência do Brasil, anos antes, revelam a dualidade campo/cidade que mobilizaria o estado em novos confrontos armados, até o pacto getulista:

Esses açorianos, tão apegados a suas terras, lavouras, lojas e oficinas, representavam a ordem, a estabilidade, o respeito às leis, a obediência à Corte de Lisboa. Mas os homens que, como Rodrigo, tinham vindo das Guerras Platinas, onde estiveram em contato com os caudilhos e guerreiros castelhanos que procuravam libertar sua pátria do domínio espanhol; os homens do interior e da fronteira que amavam a ação, o entrevero, as cargas de cavalaria, a lida e a liberdade do campo, onde viviam longe do coletor de impostos e das autoridades - esses falavam em liberdade, hostilizavam portugueses, queriam a independência. Representavam a população menos estável porém mais nativista do Rio Grande. Criavam gado, faziam tropas e eventualmente engrossavam os exércitos quando o inimigo invadia a Província. Alguns brigavam por obrigação; muitos por profissão; mas a maioria brigava por gosto (VERISSIMO, 2004, pp. 264-265).

$$
* * *
$$

Em entrevista concedida a Sandra Pesavento, Lígia Chiappini, Jacques Leenhardt e Flávio Aguiar, o grande crítico literário Antonio Candido conta que sua geração conheceu o Rio Grande através das páginas de 
Erico Verissimo: "A técnica narrativa nos fascinou e nós percebemos que ali estava um escritor que sabia ver a sociedade com os olhos retos, descrevendo sem complacência as classes dominantes e manifestando grande solidariedade em relação aos fracos e oprimidos" (PESAVENTO, 2001, p. 13). A veracidade das descrições parece se encontrar nas soluções formais, sempreadequadas aos motivos abordados eao enredo criado. Uma composição dessa natureza exigiu o conhecimento profundo da memória histórica local, como vimos. As disputas da intelectualidade gaúcha, em torno de temas por ela considerados problemáticos, renderam grandes frutos no romance de Verissimo, seja nas possibilidades de narração e expressão, na construção de personagens, no desenvolvimento da ação ou na diversidade de pontos de vista articulados. Mas diferentemente de outros autores gaúchos seus contemporâneos, Erico não tinha ambições historiográficas. Erraríamos se enxergássemos em sua obra um veredito final aos problemas levantados. Viveu entre a última geração de polígrafos locais, eruditos autodidatas que enfrentavam modalidades disciplinares e gêneros do discurso distintos, que não tinham na atividade intelectual sua principal fonte de renda, porém tornou-se seu único profissional especializado na produção literária de ficção. ${ }^{14}$ Através dessa, se posicionou, denunciou a realidade, propôs sínteses e interpretações históricas, mas o fez dentro da melhor tradição de romance realista, aquela que vê na literatura uma possiblidade de debate.

\section{REFERÊNCIAS BIBLIOGRÁFICAS}

BERTASO, José Otávio. Apresentação. In: VERISSIMO, Erico. Solo de Clarineta, vol. 1. São Paulo: Companhia das Letras, 2004, pp. 9-14.

CHAVES, Flávio Loureiro. Erico Verissimo: o escritor e seu tempo. Porto Alegre: Editora da UFRGS, 2001.

14 Tal configuração sociológica foi indicada em trabalho clássico de Sérgio Miceli: "De fato, havia apenas um grupo restrito de escritores que puderam se consagrar em tempo integral à produção de obras literárias e artísticas, seja voltado predominantemente para a produção especializada num determinado gênero - como nos casos de Erico Verissimo, Jorge Amado, José Lins do Rego, todos eles concentrando o grosso de sua produção nos romances que lançaram no mercado - seja repartindo seu tempo e seus investimentos em diversos gêneros (...)" (MICELI, 1979, p. 121). 
GONZAGA, Sergius. As mentiras sobre o gaúcho: primeiras contribuições da literatura. In: DACANAL, José Hildebrando, GONZAGA, Sérgius (orgs.). Cultura e Ideologia. Porto Alegre: Mercado Aberto, 1980, pp. 113-132.

GUTFREIND, Ieda. A historiografia Rio-grandense. Porto Alegre: Editora da UFRGS, 1992.

LEITE, Ligia Chiappini de Moraes. Regionalismo e modernismo. São Paulo: Ática, 1978.

MICELI, Sergio. Intelectuais e Classe dirigente no Brasil (1920-1945). São Paulo: Difel, 1979.

MURARI, Luciana. A construção da identidade social na literatura regionalista: o caso sulrio-grandense. Anos 9o, Porto Alegre, v. 17, n. 32, pp. 159-183, dez. 2010.

PESAVENTO, Sandra et al. Erico Verissimo: o romance da história. São Paulo: Nova Alexandria, 2001.

VERISSIMO, Erico. O continente, vol. 1. $3^{\underline{a}}$ edição. São Paulo: Companhia das Letras, 2004.

VERISSIMO, Erico. O continente, vol. 2. $3^{\text {a }}$ edição. São Paulo: Companhia das Letras, $2004 \mathrm{~b}$.

VERISSIMO, Erico. Solo de clarineta, vol. 1. 20aㅡ edição. São Paulo: Companhia das Letras, 2005 .

ZALLA, Jocelito, MENEGAT, Carla. História e memória da Revolução Farroupilha: breve genealogia do mito. Revista Brasileira de História, v. 31, n. 62, 2011, pp. 49-70.

ZILBERMAN, Regina. A literatura no Rio Grande do Sul. Porto Alegre: Mercado Aberto, 1980 . 